\title{
Practices and Changes in Public Nutrition in Slovakia During the Period of Construction of Socialism
}

\author{
RASTISLAVA STOLIČNÁ \\ Institute of Ethnology, \\ Slovak Academy of Science in Bratislava \\ rastislava.stolicna@savba.sk
}

\begin{abstract}
The study aims to describe the changes in public nutrition during the period of socialism in Slovakia. It explains the essence of the state Communist ideology's involvement in people's eating habits and the reality of food production, distribution and consumption.
\end{abstract}

KEY WORDS: socialism, politics, nutrition, Slovakia

According to Marion Nestle (2007), the study of human nutrition allows to analyse social changes. Since people need to eat, different events, processes and changes can best be grasped through food and related practices and experiences from everyday life. Food changes abstract political concepts to personal, very concrete reflections of social changes, which also applies to the topic analysed herein: practices and changes in public nutrition in Slovakia during the period of constructing socialism.

The political authoritarian regime under the leadership of the Communist Party of Czechoslovakia (CPC), established in our country in 1948, was massively involved in an entire complex of functions and norms of the society. Mainly during its first stage, in the 1950s when its ideological fundaments and essence were formed, in addition to its primary aim to win and consolidate its power it also had the vision of creating "new" socialist DOI: 10.1515/eas-2015-0014 C University of SS. Cyril and Methodius in Trnava. All rights reserved. 
people behaving and living in line with the established political line. The "new" man was one of the central figures of the socialist era in general. Their newness was in sharp contrast with tradition, but the very idea of the new model of humanity was based on the European tradition of modernity. This model promoted the independence of individuals from family and the representation of family ties by other types of collective feelings of belonging, and reflected the symptoms of general civilisation changes, such as technical progress, urbanisation, mass migration, women's emancipation, and the general cultural emancipation of the society. The Communist propaganda often referred to these phenomena and adopted them to its ideological demands (BRZÓSTOWICZ-KLAJN 2004:147). It was characteristic for this regime that it sought to form "new" people by influencing all parts of their lives, including the most intimate ones. One of the aims was to transform the "backward" rural population into a modern conscious class (BÚRIKOVÁ 2006: 83). This process resulted in the fact that most every-day situations ceased to have an individual nature and became society-wide issues. This concerned housing, clothing, education, culture, religion, sports, and, naturally, eating (PIOTROWSKI 2005:143).

With regard to production, modernisation in the socialist perception primarily focused on the development of the heavy industry and on infrastructure construction. As a result of the nationalisation of the means of production, farmers and workers did not produce for their own consumption, but sold their labour force to the state for money in the form of salary. The fact that the means of production were owned by the state and not by the people who used them, shifted their relationship to material culture towards consumption. Since collectivisation and nationalisation which took place during the first stage from 1948 to 1954 and during the second stage from 1955 to 1960, as well as during the period of nationalisation of industry which started in 1945 and was completed in 1948, most material items became the object of a consumer relationship, and not of a production one. Socialism thus completed the consumption revolution in Slovakia. These changes in consumption were presented as gradual modernisation of society and as the success of the Communist ideology (BÚRIKOVÁ 2006:83). The level of consumption - its affluence or shortage also formed people's relationship towards the socialist regime. On one hand, increased consumption and the satisfying of people's basic needs served the Communist Party to legitimise its power; on the other hand, the shortage of goods (especially basic foodstuffs) was reflected in their critical evaluation of the socialist reality (MILLER 1995:15-16).

In 1948, the leadership of the Communist Party of Czechoslovakia set out the directions and tasks of the agricultural and nutrition policy. These were closely linked to the collectivisation of agriculture, the building of farmers' cooperatives, and the paternalist administrative and directive management of economy and society. The centralised production planning through the Ministry of Agriculture, the State Planning Authority, and 
agricultural offices at regional, district and local levels were expected to restrict or eliminate the "decision-making of capitalists and small producers" (HLAVOVÁ 2006:131143). However, a large part of farmers did not welcome the nationalisation of agricultural production with enthusiasm. Local authorities sought to force those hesitating to enter a cooperative by means of material support and promises, but also under various kinds of pressure, benefits scheduling, strict exaction of unfulfilled tasks, high taxes, firing of relatives from employment or schools, or by calling "kulaks" to army work units (LIPTÁK 2000:297).

Even though the Communist propaganda was keen on accentuating the building successes of the nationalised industry and state agricultural cooperatives, the economic production sector failed to ensure sufficient supplies of products and foodstuffs to the population on the free market. As a result of this situation, the Communist regime was forced to introduce a food rationing system in the period from 1 January 1950 till 31 May 1953. Under this system, food rations were limited and allocated according to people's age and occupation. The groups privileged by the regime, such as miners, metallurgists, the police, and Communist cadres, could benefit from increased rations on the controlled market, in which they could purchase products in exchange for coupons.

Some categories of people were excluded from the rationing system, such as senior officials, police and army officers from the pre-war Czechoslovak Republic, trade licence holders, traders, etc. They could only purchase products on the free market for prices several times higher. Also smaller farmers who failed to meet mandatory supplies of meat, milk and eggs did not get coupons for sugar and other products. Members of poorperforming agricultural cooperatives that failed to ensure the set amounts of food supplies to the public sector were in a similar situation. Moreover, a decree of the Ministry of Internal Trade defined a group of self-suppliers - owners of lands of over 0.5ha - who were not entitled to food coupons. The rationing coupon system was cancelled one day before the money exchange, under which people could exchange their former money of up to 300 Czechoslovak crowns at the rate of 5:1, and higher amounts and deposits at the rate of 50:1 (JIRÁSEK-ŠŮLA 1992:16-20).

\section{Attempts to change the nutrition of socialist people}

The death of J. V. Stalin in 1953 meant a turn towards greater interest in people's living standards in the entire Soviet bloc. The professional discourse on nutrition was similar to the one on other areas of life. It highlighted not only the big importance of nutrition for society, but also its health impacts and, secondarily, its economic aspects as a means to 
increase the productivity of people's work. In the 1950s, the progress in food quality was constantly accentuated as compared to the interwar period.

A general feature of contemporary expert nutrition studies was the faith that the new people's democratic and later socialist society would bring a new life-style also in the field of nutrition by respecting the health needs of people without the desire of food producers to earn profits... Nutrition manifested most clearly the class character of the old capitalist society, while the socialist system enables full respect for biological aspects. Food ceases to be the subject of profit and becomes the means for a new socialist man to be healthy and fully efficient... This is a quote from the resolution adopted at the working conference of the Association for Proper Nutrition in 1950. For most experts, especially for physicians, this meant that they could influence people's eating habits to an extent which was previously unthinkable. The vision of a society managed by scientists was a synonym for socialism for many nutritionists (FRANC 2003: 25-29).

From the mid-1950s, Czechoslovakia launched a campaign in line with the changes in its nutrition policy, emphasising the benefits of new technologies and the need for a total transformation of people's eating habits. It was related to contemporary modernist ideas associated with the promotion of scientific knowledge in everyday life. The symbols testifying the importance of technical and biological sciences in the field of nutrition included, in particular, various kinds of processed food, especially intermediate products and different ways of food preservation. The professional and promotional materials constantly stressed that people's distrust in such food does not have actual justification; on the contrary, processed foodstuffs bring significant time savings. The growth of intermediate food products was also related to the process of "liberation" of working socialist women from housework and with the development of common catering in schools, factories, offices, etc. It was envisaged to centralise production to a maximum extent possible, and to establish an intermediate product industry as a separate food industry sector. Despite all proclaimed benefits, the popularity of intermediate food products was not as their proponents had imagined. The reason behind, according to contemporary experts, was the ignorance of the economic importance of time while preparing meals at home (HRUBÁ 1964:121). Greater dissemination of intermediate products in the countryside was prevented by the problem related to their distribution, storage, prices, and traditional eating habits.

The technical and technological development in the field of nutrition was also accompanied by a planned shift to automated, continuous food production with high production hygiene as one of the expected positive results. The issue of appropriate food packages, especially for meat, fat and milk, was of special interest (KOCIÁN 1951:69-70, 98-100, 123-125). 
Besides technological problems, the situation was complicated by the fact that compared to more developed countries, the purchase of food constituted a significant burden to Czechoslovak citizens. Economists explained this situation by the fact that other living costs, such as the costs of housing, healthcare, culture and taxes, were lower compared to capitalist countries. The high proportion of food costs, however, led to a situation where most households considered proper and healthy nutrition which was extremely expensive a luxury. People mostly criticised the high prices of meat, exotic fruit and butter. Nutritionists therefore sought to manipulate the public opinion in order to improve the conditions of public nutrition. They promoted cost advantageous foodstuffs with the aim to increase their consumption. For example, in times of insufficient consumption of milk and milk products or eggs, they stressed the low prices of this rich source of animal proteins. One of the leitmotifs of promoting a healthy diet, in addition to variety, was the need for moderation due to enormous increase in fat and sugar consumption, mainly as a result of the food coupon system. The public consumption system offered another possibility for food price manipulation and constituted one of the priority efforts of those advocating proper nutrition in the 1950s. Public catering was to become the main source of positively influencing the eating habits of the general public. In spite of the awareness raising efforts, the majority of the population continued to maintain the traditional concept of "good" food, which was acknowledged by nutrition researchers.

\section{Results of the contemporary research in the nutrition of Slovak citizens}

In the mid-1950s, public nutrition was studied by researchers from the People's Nutrition Institute in Bratislava. The results obtained from the research led by MUDr. Juraj Budlovský in 1955/1956 offer a large amount of data documenting the socialist reality in the field of nutrition. The part analysing the contents of meals in examined families represents a relevant source of information. The following facts summarise the findings:

In the countryside, certain, mainly typical regional dishes were served several times a week or even constantly throughout the week, except Sunday. This eating stereotype constituted the main difference between towns and the countryside, and was present all over Slovakia. People in towns ate less, yet more frequently; the meals were more varied and balanced, and greater attention was paid to regularity and food preparation. The biggest problem of nutrition in the countryside, especially in the mountainous northern regions, was a limited number of basic foodstuffs: cereals, potatoes, sauerkraut, and milk, i.e. foodstuffs (other than milk) containing carbohydrates which, with the low consumption of meat and eggs, had small protein content. The meals were therefore rather unbalanced in terms of nutrients (BUDLOVSKÝ 1960:63-89). 
Relevant information on the given period can be found in the part of the book by $\mathrm{J}$. Budlovský which analyses the economic factors of public nutrition, especially those related the distribution of foodstuffs. This part of the book presents a number of important facts, in particular researchers' statements on food production and distribution that had a substantial impact on the quality and balance of public nutrition. In the mid-1950s, it was mainly the lack of distribution of some basic foodstuffs in Slovakia: cream, curd, fresh meat, fruits, and vegetables. The production and distribution sectors were even unable to ensure nutrition for babies in the form of milk powder. Another problem was the imbalanced distribution between urban and rural areas; some basic foodstuffs (bread, for example) were not distributed to rural grocery stores at all, or only sporadically. In addition to insufficient and often inadequate food supplies, another factor also influenced the eating habits in the countryside - the poor network of grocery stores. Another negative factor was the seasonal character of foodstuffs, due to which contemporary distribution was not able to satisfy people's needs, i.e. to ensure enough fish during fasting periods, or enough butter, curd, eggs, meat, and fruit during festive days, etc. On the other hand, sugar consumption largely increased, which was considered a positive result, but from the point of view of proper and healthy nutrition it was rather seen as a negative condition with long-term health effects on the Slovak population. It is apparent that the research in public nutrition in 1955/1956 did not bring very optimistic results, but rather the opposite (BUDLOVSKÝ 1960:288-308).

\section{The reality of socialist food production and distribution}

The Communist ideology claimed that food production and distribution in the socialist political system depends on and is governed by the needs of broad masses of people. The centralised planned system of management failed to meet these claims, which caused, in the network of grocery stores, the lack of an appropriate range of food products in terms of quantity or quality for all population groups. Some food products were scarce, and this concerned both domestic production and imported foodstuffs.

With insufficient food supplies, people were forced to seek other sources and to ensure food mainly through self-supplies. Self-supplies of food during the period of socialism, however, cannot be understood in the same way as in the previous historic periods, when the economy supplied families with all necessary food items. In the socialist period, it was rather about home making of food products, or food received as gift or by exchange (DVOŘÁKOVÁ-JANU゚ 1999:173,147), thus supplementing or replacing purchased foodstuffs.

In the period of socialism, this type of enterprise was needed to plug the gaps caused by shortages in the formal economy. Food production in families was commonly performed 
along with other jobs, giving rise to three basic types of families in the proclaimed homogenised socialist society - depending on existence or absence of home production: self-supplier family; entrepreneur family; and user family. Their common feature was the fact that family members were employed in the state sector. According to the research conducted in 1984, up to $70 \%$ of the population developed household economy, and one tenth of them sold their products. The ownership of a garden or land was an important economic factor in Slovakia and a "social safeguard" under the socialist economic conditions. Double employment was one of the most important strategies of solving the personal situation of people (RADIČOVÁ 1993:406).

In villages, it was a specific link between traditions, social relationships and pressures, as rural people were always strongly integrated into the network of social ties (between relatives, neighbours, communities, etc.) and extensive links of mutual reciprocal dependence. Different positions, chances and appraisals were obtained in the rural society by means of certain conformity: exchange of work and payment in kind, gifts or services in return as a product of long-term reciprocity processes. Hence, "socialist" self-supply was an engaged activity of people, including a whole range of other meanings and mechanisms, such as: home-made food products as the family's economic safeguard; safety of homemade food products; people's ties to land, social control of villages and prestige of family, absence of grocery stores and of shopping opportunities, as well as relax in nature, elements of entertainment, self-realisation, and joy from attained food production. The provision for food in the socialist period was a kind of "small private happiness", considered by many people, not only from the countryside, the most important thing in their lives, restricted to a small social space and its embellishment. Works in the garden or in the field were considered a model of "meaningful" life (DVOŘÁKOVÁ-JANŮ 1999:171-172). Back in the mid-1980s, mainly older villagers considered the self-supply of food a fundamental life necessity satisfied mainly in the interest of their children and grandchildren who often lived in towns and cities. Home-made food products represented a contribution to improving the standard of their alimentation, and the money acquired from sale was used to invest in the building of a house, or in the purchase of a flat or of a car (DRÁBIKOVÁ 1985:350-361).

Since the 1970s, part of the urban population of Slovakia started to search for possibilities of weekend housing in the countryside, having purchased older rural houses, usually with gardens and orchards. In this way, they were able to produce food on their own, mostly vegetables and fruits, thus supplementing their meals. At the same time, they established contacts with the local rural inhabitants who offered them their food products for sale.

During the socialist period, garden colonies were created and expanded in city outskirts, using lands, in the exploitation of which the state had no interest. People thus 
cultivated the neglected or unsuitable land areas. The demand for such lands was enormous, as a result of which they were allocated mainly to the deserving (people of worth to the socialist society). The garden colonies created new social ties based on the same interest producing of fruits and vegetables for own consumption or for sale on the market. People exchanged their experiences, organised social events - exhibitions of their crops, evening parties, and were also involved in the "Z activity", which was a socialist competition of improving their surroundings (DRÁBIKOVÁ 1982:473-475).

In 1989, the number of gardeners who could sell their surplus crops to wholesale centres or on markets reached more than 400,000 . In addition to gardens next to private houses, gardening was another important element that helped supplying the population with fresh fruits and vegetables.

In the Slovak countryside and in smaller agrarian towns, self-supply was the principal way of ensuring the widest possible range of foodstuffs during a long historic period before the socialist era. Their variety got reduced during the period of socialism, and the range of meals prepared from home-made food at home changed, too. One of the typical examples was the cessation of home production of bread, butter, oil, etc. On the other hand, new contemporary knowledge, used in industry, was started to be used in home processing of food. One such example is slaughtering processes and products. In addition to traditional ways of meat preservation - by salt and smoke, households also used new preservation techniques, such as the use of curing salt, or sterilisation in glasses or tin cans. The popularity of home-made sausages and the possibility to buy meat casings and meat beyond the quantities obtained in home slaughters led to the fact that their production was not always connected with slaughter, and sausages started to be produced also by people living in urban areas. The range of home-made products also included ham, which was produced using similar methods as those applied in industry, mostly by means of home-made devices (ZAJONC 2006:191-192).

Home-made food products were highly appreciated during the socialist period, and, in general, were considered higher quality than those offered in groceries. People therefore sought different opportunities to obtain such foodstuffs.

Another possibility for people in the socialist system of getting quality food (and other) products from abroad or products aimed for export was shopping in TUZEX foreign trade enterprise stores. Products from these shops could be purchased for vouchers (bony) obtained in exchange for foreign currency, such as US or Canadian dollars, German marks, or Swiss or French francs. These luxury goods were accessible by people who had the possibility to get foreign exchange through their relatives living abroad or from pension for work abroad. People without such possibilities obtained vouchers illegally from dealers in 
the street right in front of TUZEX stores. Endless crowds of people stood in front of these stores mainly before holidays, wishing to buy scarce food products: alcoholic drinks, quality chocolate, Dutch cacao, instant coffee, Ovomaltine, Heinz ketchups, Wrigley's chewing-gums, etc. The category of the Communist party and state elite could also purchase relatively cheap luxury food products in well-supplied diplomatic shops, paying with Czechoslovak crowns. People who could shop in TUZEX stores or diplomatic shops were perceived by the general population as a privileged group with a higher material and social capital (ZAJONC 2006:192-193).

Quite a curiosity of socialist eating habits was the trips of Czechoslovak citizens abroad, especially to Yugoslavia since the 1960s. Even though this country formed part of the socialist bloc, it had a touch of capitalism, and it was relatively easy to get to Austria or Italy from there. It was the dream of many people to spend their holiday at the seaside in Yugoslavia in spite of the fact that they had to undergo administrative torture to be able to travel. Unless they travelled through a travel agency, they had to ask the Czechoslovak State Bank at the beginning of the year for a foreign exchange pledge with a letter of recommendation from the employer. The bank then decided whether it would sell the requested foreign exchange - Yugoslav dinars in this case - to the respective individuals. But this is not all. They were required to submit the foreign exchange pledge and the application for departure to the Ministry of Interior to receive a departure document, on the basis of which they could travel. The foreign exchange pledge was usually very low, and it was impossible to exchange Czechoslovak crowns in Yugoslavia. Those who were lucky to travel to Yugoslavia on an individual basis by car were carrying food with them to campsites and were cooking on portable propane-butane cookers. And since they usually went for a three-week holiday, it was necessary to preserve the food for as long as possible.

\section{Conclusion}

In spite of sincere efforts of mainly scientists to ensure availability, nutrition balance, variety, health and safety of foodstuffs, the reality of socialist food production and distribution in the 1950s did not reach the quality claimed by the regime. The acquisition of basic foodstuffs was associated, especially during the first two decades of this period, with feelings of discomfort in people - due to the lack of foodstuffs and their poor quality, loss of time related to food acquirement, and high prices in some cases. Naturally, these facts had a negative impact on the nutrition models of people, as families were often forced to improvise in the preparation of meals, to replace foodstuffs with those of lower quality, or often eat the same meals throughout the week. 
These conditions gradually improved during the 1970s and 1980s. Unlike in Romania and Poland, where food stores were virtually empty, people in Czechoslovakia did not really have many reasons for protests in terms of consumption (ŠEBO 2010:9-12). It was an era of full plates, called "goulash" socialism in Hungary, "dumpling and pork" socialism in the Czech Republic, or "sausage" socialism in Slovakia. Nobody starved whatever the quality of meals was. However, food production and distribution in the socialist Czechoslovakia never attained the level of developed capitalist countries connected to the globalised market. Consumption researchers (SLATER 1997, MILLER 2012) therefore note that one of the key failures causing the fall of the socialist regime was the failure to satisfy people's everyday needs.

\section{Bibliography}

BRZÓSTOWICZ-KLAJN, M. (2004): Rodziny i domu obraz. In. Lapiński, Zdislaw, Tomasik, Wojciech (eds.): Slownik realizmu socjalisticznego. [The Picture of Family and House. In. Lapiński, Zdislaw, Tomasik, W. (eds.): The Vocabulary of Socialist Realism]. Krakow.

BUDLOVSKÝ, J. (1960): Stav výživy obyvatel'stva na Slovensku. Výsledky výskumu v zimnom a jarnom obdobi 1955/1956. [The State of Public Nutrition in Slovakia: The results of the research conducted in the winter and spring of 1955/1956]. Bratislava.

BÚRIKOVÁ, Z. (2006): Spotreba a výskum reálne existujúceho socializmu. [Consumption and the Research of the Real Existing Socialism]. In. Etnologické rozpravy, No. 2, pp. 81-91.

DRÁBIKOVÁ, E. (1982): Záhradkárstvo ako súčasná záujmová forma tradícií pol'nohospodárskeho zamestnania l'udu. [Gardening as a Contemporary Spare-Time Form of Traditions of the Agricultural Work of People]. In. Slovenský národopis, 30, No. 3, pp. 473-475.

DRÁBIKOVÁ, E. (1985): Záhumienkové hospodárenie a jeho miesto v rodinnom a lokálnom spoločenstve. ( $\mathrm{Na}$ okraj zániku jednej z foriem pol'nohospodárskej malovýroby $v$ etape rozvinutého socializmu). [Small-Field Economy and Its Place in the Family and Local Community. (On the disappearance of one of the forms of smallscale agricultural production at the stage of developed socialism)]. In. Slovenský národopis, 33, №. 2-3, pp. 350-361.

DVOŘÁKOVÁ - JANU゚, V. (1999): Lidé a jídlo. [People and Food]. Praha.

FRANC, M. (2003): Řasy, nebo knedlíky? Postoje odborníků na výživu k inovacím a tradicím v české stravě v 50. a 60. letech 20. století. [Seaweeds or Dumplings? The 
attitudes of nutritionists on innovations and traditions in Czech food consumption in the 1950s and 1960s]. Praha.

HLAVOVÁ, V. (2006): Rok 1948 - rok zlomu v agrárnej politike štátu. [1948 - The Turning Point in the State Agrarian Policy]. In. Jan Pešek a kol.: Kapitolami najnovších slovenských dejín. Bratislava.

HRUBÁ, M. (1964): Polotovary v naší kuchyni. [Intermediate Products in Our Kitchen]. In. Výživa lidu, 19, No. 8.

JIRÁSEK, Z. - ŠŮLA, J. (1992): Velká peněžní loupež v Československu 1953 aneb 50:1. [Big Cash Robbery in Czechoslovakia 1953 or 50:1]. Praha.

KOCIÁN, L. (1951): Obaly na potraviny. [Food Packages]. In. Výživa lidu, 6, No. 3-5.

KRŠEK, J. (2010): Rol'níci v dobe socializmu. Takto sme žili. [Farmer in the Period of Socialism. This is How We Lived]. Bratislava.

LIPTÁK, L. (2000): Slovensko v 20. storočí. [Slovakia in the $20^{\text {th }}$ Century]. Bratislava.

MILLER, D. (2005): Consumption as the Vanguard of History: A Polemic by Way of an Introduction. In. Acknowledging Consumption. A Review of New Studies. London and New York: Routledge, pp. 1-57.

MILLER, D. (2012): Consumption and Its Consequences. Cambridge. Polity Press.

NESTLÉ, M. (2007). Food Politics. University of California Press.

PIOTROWSKI, G. (2006): PRL na talerzu: Rzeczywistość kulinarna Polski ludowej. [PRL on the Plate: Culinary Reality of the People's Poland]. In. Nationalities Affairs, 28, pp. 143-158.

RADIČOVÁ, I. (1993): Sociálny potenciál podnikavosti a prijímanie ekonomickej reformy. [The Social Potential of Enterprise and the Acceptation of the Economic Reform]. In. Sociológia, 25, No. 4-5, pp. 403-406.

SLATER, D. (1997): Consumer Culture and Modernity. London.

ŠEBO, J. (2010): Reálne 80. roky. [The Real 1980s]. Bratislava.

ZAJONC, J.(2006): Pri stole pracujúcich alebo tekvica ako ananás. [At the Workers' Table, or Pumpkin Just as Pineapple]. In. Etnologické rozpravy, No. 2, pp. 188-204. 